\title{
Philosophy of Science
}

\begin{abstract}
Editorial Board:
Jason McKenzie

Alexander

Anna Alexandrova

Jeff Barrett

Robert Batterman

William Bechtel

Gordon Belot

Cristina Bicchieri

Katherine Brading

Richard Bradley

Craig Callender

Nancy Cartwright

Lindley Darden

Michael Dickson

Stephen Downes

John Dupré

Kenny Easwaran

Doreen Fraser

Michael Friedman

Peter Gärdenfors
\end{abstract}

Andrea Woody, Editor-in-Chief

Kevin Elliott, Alan C. Love, Angela Potochnik, Katie Steele, James Owen Weatherall, and Charlotte Werndl, Associate Editors
Alan Hájek
Stephan Hartmann
Geoffrey Hellman
Don Howard
Nick Huggett
Marc Lange
Helen Longino
Jane Maienschein
Michela Massimi
Roberta Millstein
Sandra Mitchell
Mary Morgan
Wayne Myrvold
John Norton
Samir Okasha
David Papineau
Wendy Parker
Thomas Polger
Julian Reiss

Managing Editor: Kayla Mehl-Hutchinson

\section{Governing Board of the Association}

President: John Dupré, University of Exeter

President Elect: Michela Massimi, University of Edinburgh

Past President: Alison Wylie, University of British Columbia

$\begin{array}{ll}\text { Hanne Andersen } & \text { Soazig Le Bihan } \\ \text { Alisa Bokulich } & \text { Anya Plutynski } \\ \text { Hasok Chang } & \text { Jutta Schickore } \\ \text { Kareem Khalifa } & \text { Sean A. Valles }\end{array}$

Executive Director: Ryan Feigenbaum 


\section{Information for Contributors}

The policies and procedures presented here are reproduced in greater detail on the editorial office's website: https://www.philsci.org/journal.php.

Submission Method: Manuscripts should be submitted electronically via the editorial office's website: https://philsci.org/submissions.php. All electronic files should be readable in Microsoft Word or formatted as TeX or LaTeX. (Special restrictions apply to TeX and LaTeX documents; please see the website for details.) Other correspondence with the editorial office may be sent to: Philosophy of Science, Department of Philosophy, University of Washington, Box 353350, Seattle, WA 98195, USA.

Manuscripts: Submissions must not exceed 9,500 words, including abstract, footnotes, and references; a word count must be submitted with each essay. Manuscripts should be submitted in a form suitable for blind review and should include an abstract of approximately 100 words. Authors are strongly encouraged to employ a clear, reader-friendly writing style.

Discursive footnotes (consecutively numbered) should be kept to a minimum. Simple citations can be made in the text, by citing author and year of publication (with page number if necessary); a bibliography should appear on a separate page at the end. A detailed guide to the reference style appears on the website.

Copyright: Manuscripts should be submitted to Philosophy of Science with the understanding that upon acceptance for publication copyright will be transferred to the Philosophy of Science Association.

Book Reviews: Books intended for review should be sent to the address given above. Persons wishing to review a book should contact the editorial office.

Correspondence concerning PSA business matters should be addressed to Ryan Feigenbaum, Executive Director, Philosophy of Science Association, University of Cincinnati, Cincinnati, OH 45221 (e-mail: director@philsci.org). The Philosophy of Science Association website is at https://www.philsci.org. 


\section{VOLUME 88 • NUMBER $2 \cdot$ APRIL 202 I \\ Philosophy of Science}

\section{Contents}

189 There Are No Mathematical Explanations

JAAKKO KUORIKOSKI

213 Why Simpler Computer Simulation Models Can Be Epistemically

Better for Informing Decisions

Casey Helgeson, Vivek Srikrishnan, Klaus Keller, AND NANCY TUANA

234 The Function of Boundary Conditions in the Physical Sciences

Julia R. S. Bursten

258 Proof of Concept Research

Steve Elliott

281 Can Quantum Thermodynamics Save Time?

NoEl Swanson

303 A Justification of the Probabilistic Explanation of the Entropy Principle LAURENT JODOIN

320 Metainduction over Unboundedly Many Prediction Methods: A Reply to Arnold and Sterkenburg

GERHARD SCHURZ

341 A Structural Justification of Probabilism: From Partition Invariance to Subjective Probability

HANNES LeITGEB

Book Review

366 Nancy Cartwright: Nature, the Artful Modeler: Lectures on Laws, Science, How Nature Arranges the World and How We Can Arrange It Better,

reviewed by WaLter Veit 


\section{Essay Review}

370 Demarcating and Judging Medicine: Review of Broadbent's "Philosophy of Medicine"

JONATHAN FULLER

377 Referees for Philosophy of Science 
Philosophy of Science (ISSN 0031-8248) is published January, April, July, October, and December by The University of Chicago Press, 1427 E. 60th Street, Chicago, IL 60637.

Periodicals postage paid at Chicago, IL, and at additional mailing points.

Postmaster: Send address changes to Philosophy of Science, The University of Chicago Press, 1427 E. 60th Street, Chicago, IL 60637, or subscriptions @ press.uchicago.edu.

\section{Membership and Subscription Rates}

Individual subscription rates for 2021 are tiered based on income and start at \$36 print + electronic, \$27 e-only. Institutional print + electronic and e-only subscription rates are tiered according to an institution's type and research output: $\$ 307$ to $\$ 645$ print + electronic, $\$ 267$ to $\$ 561$ e-only. Institutional print-only is $\$ 352$. Additional taxes or postage for non-US subscriptions may apply. For additional rates, including full-run access, rates for single copies, and reduced rates for students, visit http://www.journals .uchicago.edu/journals/phos/about. Free or deeply discounted access is available in most developing nations through the Chicago Emerging Nations Initiative (http:// www.journals.uchicago.edu/ceni).

\section{Editorial Correspondence}

Send all editorial correspondence to Philosophy of Science, Department of Philosophy, University of Washington, Box 353350, Seattle, WA 98195. E-mail: journal@philsci .org. Information regarding submission of manuscripts can be found on the inside back cover of every issue or on our website: https://www.philsci.org/journal.php.

\section{Copying Beyond Fair Use}

Articles may be copied or otherwise reused without permission only to the extent permitted by Sections 107 and 108 of the US Copyright Law. Permission to copy articles for personal, internal, classroom, or library use may be obtained from the Copyright Clearance Center (http://www.copyright.com/). For all other uses, such as copying for general distribution, for advertising or promotional purposes, for creating new collective works, or for resale, please contact Permissions Coordinator, Journals Division, University of Chicago Press, 1427 E. 60th St., Chicago, IL 60637, USA. Fax: (773) 834-3489. E-mail: journalpermissions@ @ress.uchicago.edu. Articles in the public domain may be used without permission, but it is customary to contact the author.

Articles appearing in Philosophy of Science are abstracted or indexed in Arts and Humanities Citation Index, Biological Abstracts, Bulletin Signalétique 519, Current Contents/Arts and Humanities, Current Contents/Social and Behavioral Sciences, Current Index to Statistics, Humanities Index, Index to Book Reviews in the Humanities, Isis Critical Bibliography, Language \& Language Behavior Abstracts, Mathematical Reviews, Philosopher's Index, Philosophic, Psychological Abstracts, Repertoire Bibliographique de la Philosophie, Social Sciences Citation Index, Sociological Abstracts.

(C) 2021 by Philosophy of Science Association. All rights reserved. 